\title{
Experimental infection of rainbow trout Oncorhynchus mykiss with viral haemorrhagic septicaemia virus isolates from European marine and farmed fishes
}

\author{
Helle Frank Skall ${ }^{1, *}$, Wilhelmina J. Slierendrecht ${ }^{1,3}$, Julie A. King ${ }^{2}$, \\ Niels Jørgen Olesen ${ }^{1}$ \\ ${ }^{1}$ Danish Institute for Food and Veterinary Research, Department of Poultry, Fish and Fur Animals, Hangøvej 2, \\ 8200 Århus N, Denmark \\ ${ }^{2}$ FRS Marine Laboratory, PO Box 101, Victoria Road, Aberdeen AB11 9DB, UK \\ ${ }^{3}$ Present address: BioMar A/S, Mylius Erichsensvej 35, 7330 Brande, Denmark
}

\begin{abstract}
The susceptibility of rainbow trout Oncorhynchus mykiss to infection with various isolates of viral haemorrhagic septicaemia virus (VHSV) was examined. A total of 8 experiments with rainbow trout ranging from 0.6 to $6.2 \mathrm{~g}$ was conducted for 139 isolates originating from wild marine fishes in European waters (115 isolates), farmed turbot from Scotland and Ireland (2 isolates), and farmed rainbow trout (22 isolates). The isolates were tested by immersion and/or intraperitoneal injection either as pooled or single isolates. The isolates from wild marine fishes did not cause mortality by immersion while some of the isolates caused mortality when injected. All VHSV isolates from farmed rainbow trout caused significant mortality by immersion. Currently, pathogenicity trials are the only way to differentiate VHSV isolates from wild marine fishes and farmed rainbow trout. The 2 farmed turbot isolates did not cause mortality by immersion, supporting the view that they originated from the marine environment.
\end{abstract}

KEY WORDS: VHSV $\cdot$ Infection trials $\cdot$ Rainbow trout $\cdot$ Pathogenicity

\section{INTRODUCTION}

Viral haemorrhagic septicaemia virus (VHSV) is one of the most serious viral pathogens affecting cultured rainbow trout Oncorhynchus mykiss in Europe. In the last decade, VHSV has been isolated on numerous occasions from the marine environment, in European (Jensen et al. 1979, Jørgensen \& Olesen 1987, Smail 1995, 2000, Dixon et al. 1997, Mortensen et al. 1999, King et al. 2001b, Brudeseth \& Evensen 2002), North American (Brunson et al. 1989, Meyers \& Winton 1995, Meyers et al. 1999, Traxler et al. 1999, Cox \& Hedrick 2001) and Japanese (Takano et al. 2000) waters.

The implication is that there is a marine reservoir for VHSV that may affect mariculture or freshwater fish farms. Anadromous fishes migrating upstream could act as potential carriers, and feeding farmed fishes with untreated wild-caught marine fish could present a source of infection.

The North American strain of VHSV is highly pathogenic for Pacific herring Clupea pallasi (Kocan et al. 1997), and the European marine VHSV isolates are pathogenic for turbot Scophthalmus maximus (King et al. 2001a).

The VHSV isolates from marine fish species are serologically very similar to isolates from VHS outbreaks in farmed rainbow trout (authors' unpubl. data). Genetically, the VHSV isolates from marine fish group together in phylogenetic trees constructed from glycoprotein $(\mathrm{G})$ and nucleoprotein $(\mathrm{N})$ gene sequences (Snow et al. 1999, K. Einer-Jensen unpubl. data). How- 
ever, techniques have not been established to clearly distinguish VHSV isolates of different origins.

The UK and most of Scandinavia are approved VHSand IHN (infectious haematopoietic necrosis)-free zones according to the European Union legislation (Council Directive 91/67/EC). The isolation of VHSV in the coastal waters of these areas could be a serious threat to this zoning status unless a clear distinction between pathogenic and non-pathogenic isolates can be made.

The purpose of this study was to determine the pathogenicity to rainbow trout of a large number of VHSV isolates representing all European marine fish species known to carry the virus. In addition, a number of VHSV isolates from farmed rainbow trout were examined for comparison.

\section{MATERIALS AND METHODS}

We conducted 4 infection trials by immersion and 2 by intraperitoneal (i.p.) injection, using 115 VHSV isolates from wild marine fish species and 2 isolates from farmed turbot. The tested marine isolates comprised $62 \%$ of the approximate 190 European marine isolates (Dixon et al. 1997, Mortensen et al. 1999, Smail 2000, King et al. 2001b, Brudeseth \& Evensen 2002, H. F. Skall unpubl. data, A. Hellström unpubl. data) that have been obtained to date. In addition, an infection trial was performed by immersion using 22 VHSV isolates from farmed rainbow trout from Denmark.

Fish. Rainbow trout fry or eyed eggs, reared to fry in the laboratory, originated from commercial fish farms officially registered as free from IPN (infectious pancreatic necrosis) and VHS viruses.

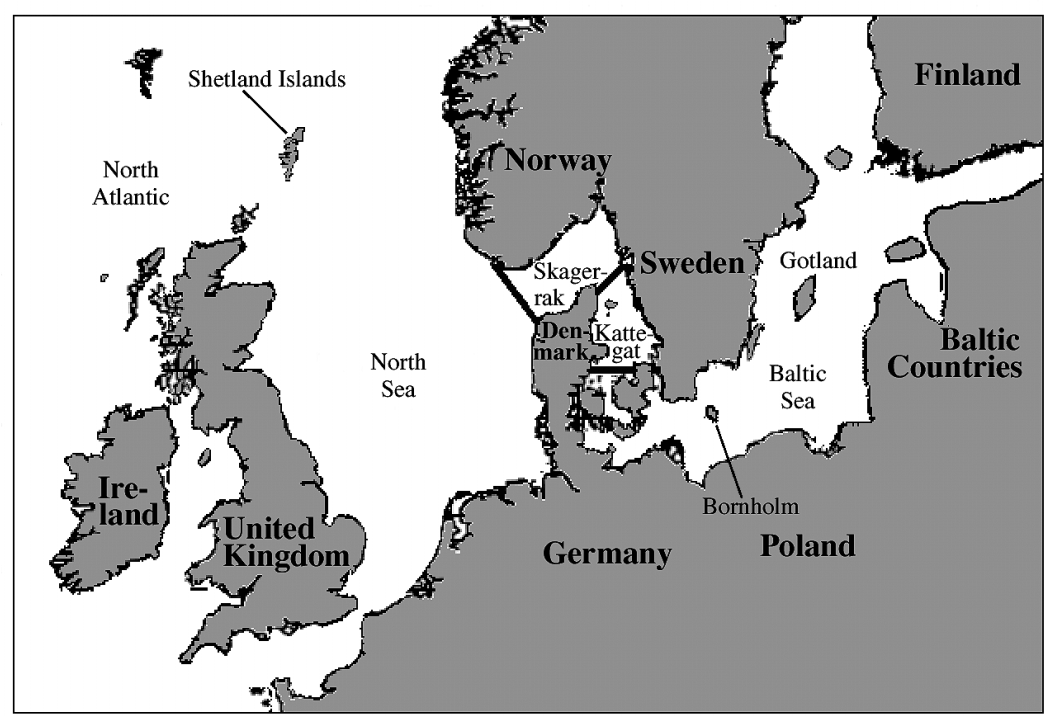

Fig. 1. Map showing waters in northern Europe from which marine VHSV isolates originated
Tanks. The tanks contained 81 soft fresh water (1 to $3.5^{\circ} \mathrm{d}$ ) maintained at 10 to $14^{\circ} \mathrm{C}$. The water source was continuously flowing unchlorinated groundwater of drinking quality. The water was aerated and the tanks were covered with transparent lids to avoid aerosols and prevent the fish from jumping out. Each group was tested in triplicate.

Virus isolates. The virus isolates, original hosts and capture locations are listed in Table 1 and a map indicating the waters from which the marine isolates originated is shown in Fig. 1.

All isolates in the infection trials were of low passage numbers (maximum 5 passages) that were propagated and titrated on BF-2 cells, according to standard procedures (Lorenzen et al. 1988).

All the virus isolates were individual isolates, each coming from 1 sample consisting of organs from single or pooled fish.

Immersion Trial I used European isolates from marine fishes that were available at the time. These isolates were also tested by i.p. injection after pooling the isolates in i.p. Trial I, and a selection of these isolates were then tested singly in i.p. Trial II. Immersion Trial II featured a new isolate from farmed turbot, and Immersion Trials III and IV examined new isolations from wild marine fishes.

In Immersion Trial V, rainbow trout were exposed to Danish VHSV isolates originating from farmed rainbow trout. The farms were either fresh water or marine. The isolates were from VHS outbreaks on individual farms, from fish showing clinical signs of VHS. The isolates were chosen so that Neutralisation Patterns I, II and III (Olesen et al. 1993) and a temporal period from 1985 to 1998 were represented.

Infection trials. The number of isolates, size of rainbow trout and number of fish in each tank are shown in Table 2.

Numbers of dead fish and their clinical signs of VHS were noted and removed from each tank daily. When each trial was terminated (after 21 or 22 d), the surviving fish were euthanised with an overdose of benzocaine and counted. The sum of surviving fish and fish that died during the trial equalled the number of fish in each tank. Except in the positive and negative control tanks, if none or only a few fish died, then 3 fish from each tank were sampled for virus isolation on Days 7 and 14. For Immersion Trial II, 1 tank was additionally sampled on Day 9. In the case of mortality due to VHS for groups infected by immersion using pooled 
Table 1. VHSV isolates tested in infection trials with Oncorhynchus mykiss. Patterns I, II, III are Neutralisation Patterns I, II and III, respectively; -: no data; SW: sea water; FW: fresh water

\begin{tabular}{|c|c|c|c|c|c|c|c|}
\hline Isolates & Site & Host & $\begin{array}{l}\text { Wild/ } \\
\text { farmed }\end{array}$ & Water & Year & Pattern & Source \\
\hline 4 p37 & North Sea & Micromesistius poutassou & Wild & SW & 1997 & - & 1 \\
\hline M. rhabdo & Baltic Sea & Gadus morhua & Wild & SW & 1979 & - & 2,3 \\
\hline $1 \mathrm{e} 62,1 \mathrm{p} 54,1 \mathrm{p} 93,1 \mathrm{p} 109$ and 1p116 & Baltic Sea & Gadus morhua & Wild & SW & 1996 & - & 1 \\
\hline MLA98/4CO1 & North Atlantic & Gadus morhua & Wild & SW & 1998 & - & 4 \\
\hline H17/5/93 and H19/1/93 & North Sea & Gadus morhua & Wild & SW & 1993 & - & 5 \\
\hline $\mathrm{H} 16 / 7 / 95$ & North Sea & Gadus morhua & Wild & SW & 1995 & - & 6 \\
\hline $4 \mathrm{p} 59$ & North Sea & Gadus morhua & Wild & SW & 1997 & - & 1 \\
\hline $5 \mathrm{p} 405$ & Baltic Sea & Limanda limanda & Wild & SW & 1998 & - & 7 \\
\hline $5 \mathrm{p} 26,5 \mathrm{p} 28,5 \mathrm{p} 48,5 \mathrm{e} 59,5 \mathrm{e} 62$ and $5 \mathrm{e} 63$ & Kattegat & Limanda limanda & Wild & SW & 1998 & - & 7 \\
\hline $5 \mathrm{e} 454$ & Baltic Sea & Platichthys flesus & Wild & SW & 1998 & - & 7 \\
\hline H17/1/95 and H17/2/95 & North Sea & Melanogrammus aeglefinus & $S$ Wild & SW & 1995 & - & 6 \\
\hline \multicolumn{8}{|c|}{ 1p3, 1p8, 1p12, 1p49, 1p53, 1p64, 1p85, } \\
\hline $1 \mathrm{p} 110,1 \mathrm{p} 120$ and $1 \mathrm{p} 125$ & Baltic Sea & Clupea harengus & Wild & SW & 1996 & - & 1 \\
\hline \multicolumn{8}{|l|}{ 5p393, 5p439, 5p441,5p442,5p448, } \\
\hline \multicolumn{8}{|l|}{ 5p449, 5p508, 5p547, 5p551, 5p557, } \\
\hline \multicolumn{8}{|l|}{ 5p663, 5e685, 5e689, 5e691, 5e693, } \\
\hline \multicolumn{8}{|l|}{ 5е $702,5 е 709,5 p 745,5 p 748,5 p 752$} \\
\hline $5 p+57,5 p+81$ and $5 p+95$ & Baltıc Sea & Clupea harengus & Wild & SW & 1998 & - & 7 \\
\hline $96-43$ & English Channel & Clupea harengus & Wild & SW & 1996 & - & 8 \\
\hline \multicolumn{8}{|l|}{ 5p31, 5p201, 5p213, 5p251, 5p253 } \\
\hline and $5 \mathrm{p} 263$ & Kattegat & Clupea harengus & Wild & SW & 1998 & - & 7 \\
\hline SVA $74-20$ & Kattegat & Clupea harengus & Wild & SW & 1998 & - & 9 \\
\hline $4 \mathrm{p} 168$ & Skagerrak & Clupea harengus & Wild & SW & 1997 & - & 1 \\
\hline 4p51 & North Sea & Argentina sphyraena & Wild & SW & 1997 & - & 1 \\
\hline \multicolumn{8}{|l|}{ MLA98/4PT1, MLA98/4PT2, } \\
\hline \multicolumn{8}{|l|}{ MLA98/4PT3, MLA98/4PT4, } \\
\hline MLA98/4PT5 and MLA98/4PT6 & North Atlantic & Trisopterus esmarki & Wild & SW & 1998 & - & 10 \\
\hline 2p51 & Skagerrak & Trisopterus esmarki & Wild & SW & 1996 & - & 1 \\
\hline $5 \mathrm{p} 276$ & Kattegat & Pleuronectes platessa & Wild & SW & 1998 & - & 7 \\
\hline $5 \mathrm{p} 11$ & Skagerrak & Pleuronectes platessa & Wild & SW & 1998 & - & 7 \\
\hline MLA98/4PC1 & North Atlantic & Trisopterus minutus & Wild & SW & 1998 & - & 10 \\
\hline $1 \mathrm{p} 40$ & Baltic Sea & Rhinonemus cimbrius & Wild & SW & 1996 & - & 1 \\
\hline \multicolumn{8}{|c|}{ 1p50, 1p52, 1p55, 1p86, 1p111, 1p121, } \\
\hline $1 \mathrm{p} 124$ and $1 \mathrm{p} 128$ & Baltic Sea & Sprattus sprattus & Wild & SW & 1996 & - & 1 \\
\hline \multicolumn{8}{|l|}{ 5p457, 5p513,5p514, 5p524,5p527, } \\
\hline \multicolumn{8}{|l|}{ 5p669, 5p670, 5p671, 5p672, 5p673, } \\
\hline \multicolumn{8}{|l|}{ 5p674, 5p675, 5p676, 5p677, 5p678, } \\
\hline \multicolumn{8}{|l|}{ 5p679, 5p680, 5p681, 5p682,5p683 } \\
\hline \multicolumn{8}{|l|}{$\begin{array}{l}\text { 5p } 761,5 \mathrm{p} 785,5 \mathrm{p} 791, \text { bris } 3 \text {, bris } 4, \\
\text { bris } 8 \text {, bris } 9 \text {, bris } 10 \text { and bris } 11\end{array}$} \\
\hline $4 \mathrm{p} 100$ and $4 \mathrm{p} 101$ & Skagerrak & Merlangius merlangus & Wild & SW & 1997 & - & 1 \\
\hline F13.02.97 & Cape Clear, Ireland & Scophthalmus maximus & Farmed & SW & 1997 & - & 11 \\
\hline $860 / 94$ & Gigha, Scotland & Scophthalmus maximus & Farmed & SW & 1994 & - & 12 \\
\hline DK-6047 & Denmark & Oncorhynchus mykiss & Farmed & SW & 1991 & $\mathrm{I}$ & 7 \\
\hline DK-9695152 & Denmark & Oncorhynchus mykiss & Farmed & SW & 1996 & III & 7 \\
\hline DK-3345 & Denmark & Oncorhynchus mykiss & Farmed & FW & 1985 & $\mathrm{I}$ & 7 \\
\hline DK-3592B-positive control & Denmark & Oncorhynchus mykiss & Farmed & FW & 1986 & I & 13 \\
\hline DK-3955 and DK-3956 & Denmark & Oncorhynchus mykiss & Farmed & FW & 1987 & I & 7 \\
\hline DK-5133 & Denmark & Oncorhynchus mykiss & Farmed & FW & 1988 & II & 7 \\
\hline DK-5243 & Denmark & Oncorhynchus mykiss & Farmed & FW & 1988 & $\mathrm{I}$ & 7 \\
\hline DK-6143 & Denmark & Oncorhynchus mykiss & Farmed & FW & 1991 & $\mathrm{I}$ & 7 \\
\hline DK-6435 & Denmark & Oncorhynchus mykiss & Farmed & FW & 1992 & II & 7 \\
\hline DK-7054 & Denmark & Oncorhynchus mykiss & Farmed & FW & 1993 & III & 7 \\
\hline \multicolumn{8}{|l|}{ DK-7217, DK-7299, DK-7300, DK-7309, } \\
\hline DK-7534 and DK-7655 & Denmark & Oncorhynchus mykiss & Farmed & FW & 1994 & III & 7 \\
\hline DK-7824 & Denmark & Oncorhynchus mykiss & Farmed & FW & 1995 & III & 7 \\
\hline DK-7843 & Denmark & Oncorhynchus mykiss & Farmed & FW & 1995 & II & 7 \\
\hline DK-9795159 and DK-9795265 & Denmark & Oncorhynchus mykiss & Farmed & FW & 1997 & III & 7 \\
\hline DK-9895174 & Denmark & Oncorhynchus mykiss & Farmed & FW & 1998 & III & 7 \\
\hline
\end{tabular}


isolates, each isolate in that pool was subsequently tested individually. When fish died due to VHS in i.p.challenged groups using pooled isolates, some, but not all, isolates were tested individually.

Positive and negative controls. The highly pathogenic VHSV Strain DK-3592B (Lorenzen et al. 1993), isolated from a rainbow trout farm was used as a positive control in all either immersion or i.p.-injection experiments. Dilution medium or $0.9 \% \mathrm{NaCl}$ solution was used as a negative control by immersion or i.p. injection.

Immersion trials. The virus isolates were tested either singly or in pools of up to 10 to maximise the number of virus isolates tested in each trial. The pools generally contained virus isolates from the same fish species. Virus isolates were pooled in a vial according to respective titres to obtain a concentration of $10^{5}$ $\mathrm{TCID}_{50} \mathrm{ml}^{-1}$ water/virus isolate, and were diluted as a pool to a final volume of at least $10 \mathrm{ml}$ in Eagles minimal essential medium with Tris-buffer and $10 \%$ newborn calf serum (dilution medium). The virus dilutions were added to each tank for static exposure of 1.25 to $2 \mathrm{~h}$, after which the water flow was resumed.

Intraperitoneal (i.p.) injection trials. Virus isolates were mixed with $0.9 \% \mathrm{NaCl}$ (i.p. Injection I) or dilution medium (i.p. Injection II) to obtain $10^{5} \mathrm{TCID}_{50} \mathrm{fish}^{-1}$ virus isolate $^{-1}$ per dose of either 20 or $50 \mu \mathrm{l}$ per fish, according to body size. The fish were anaesthetised in a benzocaine bath, injected intraperitoneally with a new needle and syringe for each isolate, and transferred to tanks supplied with running fresh water. In i.p. Injection II 2 tanks leaked during the first night, and most of the fish died, leaving 2 groups (Isolates 860/94 and 4p37) as duplicates.

Masking of pathogenic viruses. A non-pathogenic virus (1p8) (tested by immersion) was mixed with path- ogenic virus (DK-3592B) in the ratio 4:1 and tested in Immersion Trial I to examine whether non-pathogenic viruses masked highly pathogenic viruses when pooled together. A similar test was conducted by injection in i.p. Injection I.

Virus isolation. Fish that died during the trials and the survivors were sampled for virus isolation including the negative and positive control groups. Each fish or pool of dead fish (up to 12 fish pool ${ }^{-1}$ ) was placed in a vial with 4 $\mathrm{ml}$ dilution medium or in a plastic bag, and frozen at -25 or $-80^{\circ} \mathrm{C}$ until later examination. The tissue was homogenised in a mortar with pestle and sterile sand, diluted 1:10 in dilution medium, treated with gentamicin overnight, and inoculated on BF-2 cells as described previously (Mortensen et al. 1999). Virus isolations were confirmed as VHSV by ELISA (Olesen \& Jørgensen 1991) with the following modifications: the plate was incubated for $1 \mathrm{~h}$ at $37^{\circ} \mathrm{C}$ instead of $30 \mathrm{~min}$, and the horseradish-peroxidase (HRP)-conjugated rabbit anti-VHSV antiserum was replaced with the monoclonal antibody IP5B11 (Lorenzen et al. 1988) and a subsequent layer of HRP-conjugated rabbit anti-mouse immunoglobulins (P0260; DAKO A/S, Denmark).

Statistical analysis. Cumulative mortalities at the end of a trial within and between the different groups in each experiment were compared by a $\chi^{2}$-test (Dunn 1977). If the $\mathrm{p}$-value was $<0.05$, the difference was regarded as significant. The tendency lines (see Figs. $7 \&$ 9) were produced using Microsoft ${ }^{\circledR}$ Excel 97 SR-2.

\section{RESULTS}

A total of 115 VHSV isolates from wild marine fishes, 2 from farmed turbot and 22 from farmed rainbow trout

Table 2. Oncorhynchus mykiss. Results of all infection trials. Wt: mean weight at start of trials; $\mathrm{N}$ tank ${ }^{-1}$ : approximate no. of fish per tank; Live fish, Dead fish: data for live fish sampled on Days 7 and 14 and for survivors at end of trial, and data for fish that died during the trial, respectively (positive and negative controls not included); VHSV+/total: VHSV-positive samples/total samples; Min-Max\% VHSV+: calculated minimum and maximum \% VHSV-positive fish, where calculated minimum = 1 VHSV-positive fish in a positive sample and calculated maximum = all fish VHSV-positive in a positive sample; i.p.: intraperitoneal; nd: no data

\begin{tabular}{|c|c|c|c|c|c|c|c|c|c|c|c|c|c|c|}
\hline \multirow{3}{*}{ Trial } & \multirow{3}{*}{$\begin{array}{l}\text { No. of } \\
\text { isolates }\end{array}$} & \multirow{3}{*}{$\begin{array}{l}\text { Wt } \\
(\mathrm{g})\end{array}$} & \multirow{3}{*}{$\begin{array}{c}\mathrm{N} \\
\operatorname{tank}^{-1}\end{array}$} & \multirow{2}{*}{\multicolumn{3}{|c|}{$\begin{array}{l}\text { Cumulative } \\
\text { mortality (\%) }\end{array}$}} & \multirow{2}{*}{\multicolumn{2}{|c|}{ Day 7}} & \multicolumn{4}{|c|}{ _ Live fish } & \multicolumn{2}{|c|}{ Dead fish } \\
\hline & & & & & & & & & Day & 14 & & rvivors $^{\mathrm{b}}$ & & \\
\hline & & & & $\begin{array}{l}\text { Trial } \\
\text { group }\end{array}$ & $\begin{array}{l}\text { Neg. } \\
\text { control }\end{array}$ & $\begin{array}{l}\text { Pos. } \\
\text { control }\end{array}$ & $\begin{array}{l}\text { VHSV+ } \\
\text { /total }\end{array}$ & $\begin{array}{l}\text { Min-Max } \\
\text { \%VHSV+ }\end{array}$ & $\begin{array}{c}\text { VHSV+ } \\
\text { /total }\end{array}$ & $\begin{array}{l}\text { Min-Max } \\
\% \text { VHSV+ }\end{array}$ & $\begin{array}{l}\text { VHSV+ } \\
\text { /total }\end{array}$ & $\begin{array}{l}\text { Min-Max } \\
\% \text { VHSV+ }\end{array}$ & $\begin{array}{c}\text { VHSV+ } \\
\text { /total }\end{array}$ & $\begin{array}{l}\text { Min-Max } \\
\text { \%VHSV+ }\end{array}$ \\
\hline Immersion I & 31 (pooled) & 1 & 35 & $0-3$ & 0 & 99 & $16 / 108^{a}$ & 8 & $1 / 108^{\mathrm{a}}$ & 1 & $3 / 108$ & $0.2-3$ & $0 / 5^{\mathrm{a}}$ & 0 \\
\hline Immersion II & 1 (singly) & 2.2 & 35 & 3 & 5 & 95 & $1 / 12^{\mathrm{a}, \mathrm{c}}$ & 8 & $1 / 9^{\mathrm{a}}$ & 11 & $0 / 4$ & 0 & $1 / 3^{\mathrm{a}}$ & 33 \\
\hline Immersion III & 6 (pooled) & 3 & 35 & 2 & 4 & 87 & $0 / 9^{\mathrm{a}}$ & 0 & $0 / 9^{\mathrm{a}}$ & 0 & $0 / 5$ & 0 & $0 / 2^{\mathrm{b}}$ & 0 \\
\hline Immersion IV & 79 (pooled) & 0.6 & 60 & $5-13$ & 5 & 100 & $4 / 42^{\mathrm{b}}$ & $3-10$ & $3 / 42^{\mathrm{b}}$ & $2-7$ & $3 / 42$ & $1-7$ & $38 / 94^{\mathrm{b}}$ & $30-49$ \\
\hline Immersion V & 22 (singly) & 6.2 & 25 & $46-89$ & 4 & 88 & nd & & nd & & nd & & $93 / 95^{\mathrm{b}}$ & $40-99$ \\
\hline i.p. I & 38 (pooled) & 2.2 & 35 & $13-42$ & 5 & 94 & nd & & nd & & $6 / 13$ & $5-50$ & $57 / 74^{\mathrm{a}}$ & 77 \\
\hline i.p. II & 20 (singly) & 3 & 35 & $0-43$ & 4 & 99 & $8 / 23^{b}$ & $14-49$ & $5 / 23^{b}$ & $7-22$ & $8 / 56^{\mathrm{d}}$ & $2-14^{\mathrm{d}}$ & & \\
\hline & & & & & & & & & & & $0 / 37^{\mathrm{e}}$ & $0^{\mathrm{e}}$ & $110 / 142^{b}$ & $57-82$ \\
\hline & & & & & & & & & & & $8 / 19^{f}$ & $5-46^{\mathrm{f}}$ & & \\
\hline
\end{tabular}


were tested in 4 immersion trials and 2 i.p. trials. A summary of the different experiments and the results of virological examination are shown in Table 2 . The cumulative mortality for each trial group and the individual isolates used are shown in Figs. 2 to 5.

High mortality (87 to $100 \%$ ) occurred in the positivecontrol rainbow trout in all trials, with clinical signs of VHS and isolations of VHSV from dead fish. Low mortality in the negative-control fish ranged from 0 to $9 \%$, with no clinical signs of disease or virus isolations.

\section{Immersion Trial I}

We tested 30 VHSV isolates from wild marine fishes and 1 isolate from farmed turbot on $1 \mathrm{~g}$ rainbow trout by bath exposure. The 12 triplicate groups of rainbow trout were exposed to pools of 1 to 5 virus isolates pooled according to the original host (Fig. 2). None of the test fish displayed increased mortality or clinical signs of disease. The cumulative mortality within replicate groups differed from 0 to 3 percent points (i.e. percent of the tank population at the onset of the experiment), with no statistical difference when examined by a $\chi^{2}$-test. These results showed that the 31 VHSV isolates were non-pathogenic to rainbow trout.

The mortality in the group exposed to a mixture of pathogenic and non-pathogenic VHSV was $97 \%$ and similar to the mortality in the group exposed only to the pathogenic DK-3592B isolate (99\%). Thus, there appeared to be no masking of virulence by nonpathogenic viruses when pooled.

\section{Injection Trial I and Immersion Trial II}

In the second trial (i.p. I), the virus isolates tested in Immersion Trial I together with some new isolates were tested by i.p. injection in $2.2 \mathrm{~g}$ rainbow trout (Fig. 4). An immersion trial with a recent isolate from farmed rainbow trout was also performed (Immersion Trial II) (Fig. 2).

A total of 7 triplicate groups were injected with pools of 1 to 9 VHSV isolates from marine fish species. In all, 38 isolates were pooled according to the original host (Fig. 4). The rainbow trout injected with the marine VHSV isolates showed typical signs of VHS (haemor-

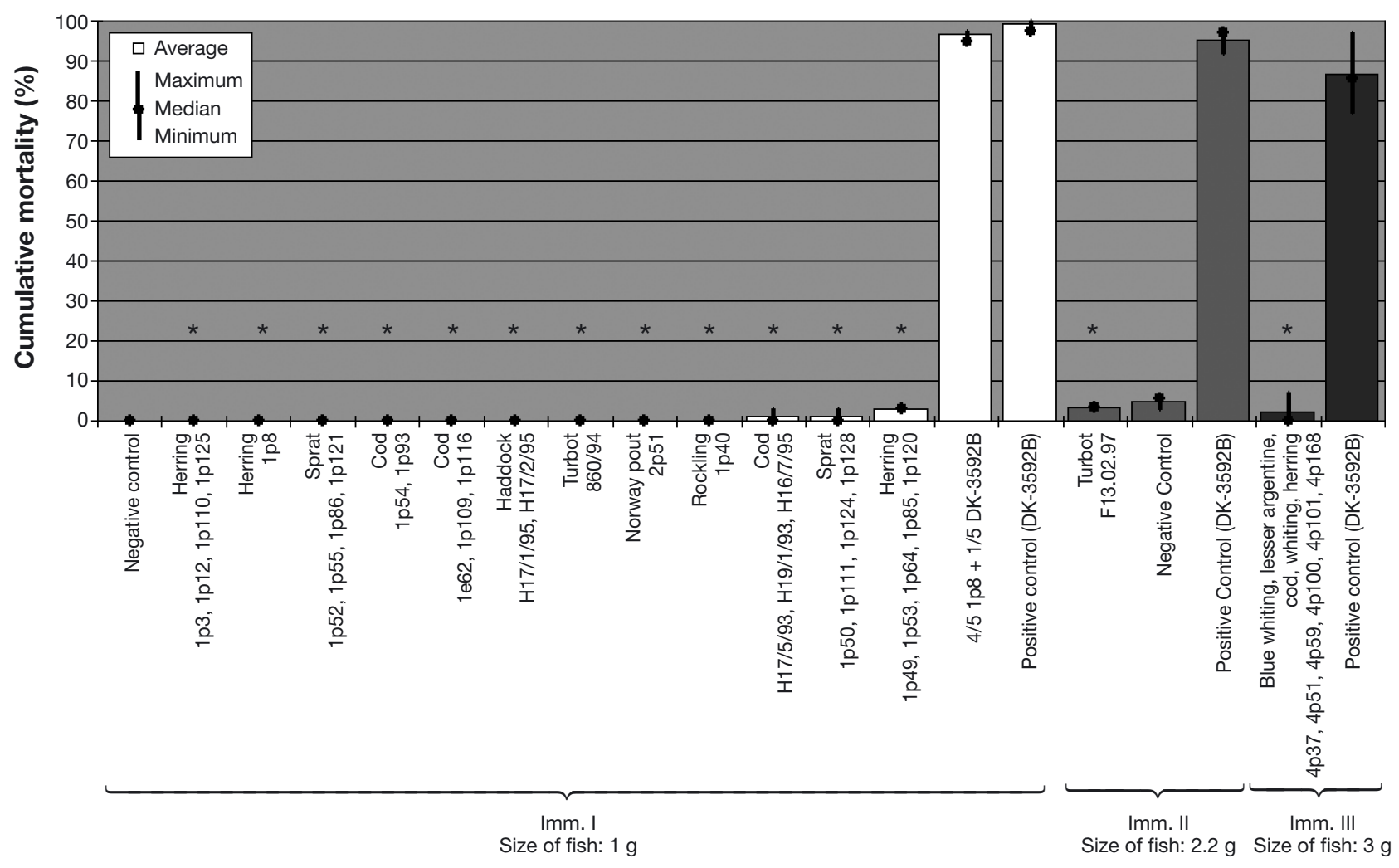

Fig. 2. Oncorhynchus mykiss. Cumulative mortality in Immersion Trials I, II and III using VHSV isolates from wild marine fishes and from farmed turbot suspected to be of marine origin. Cumulative mortality at end of trial is shown as average, minimum, median and maximum mortality for each group. ${ }^{*}$ Group not significantly different from negative control group. Isolate descriptions and specific names of host species are given in Table 1 


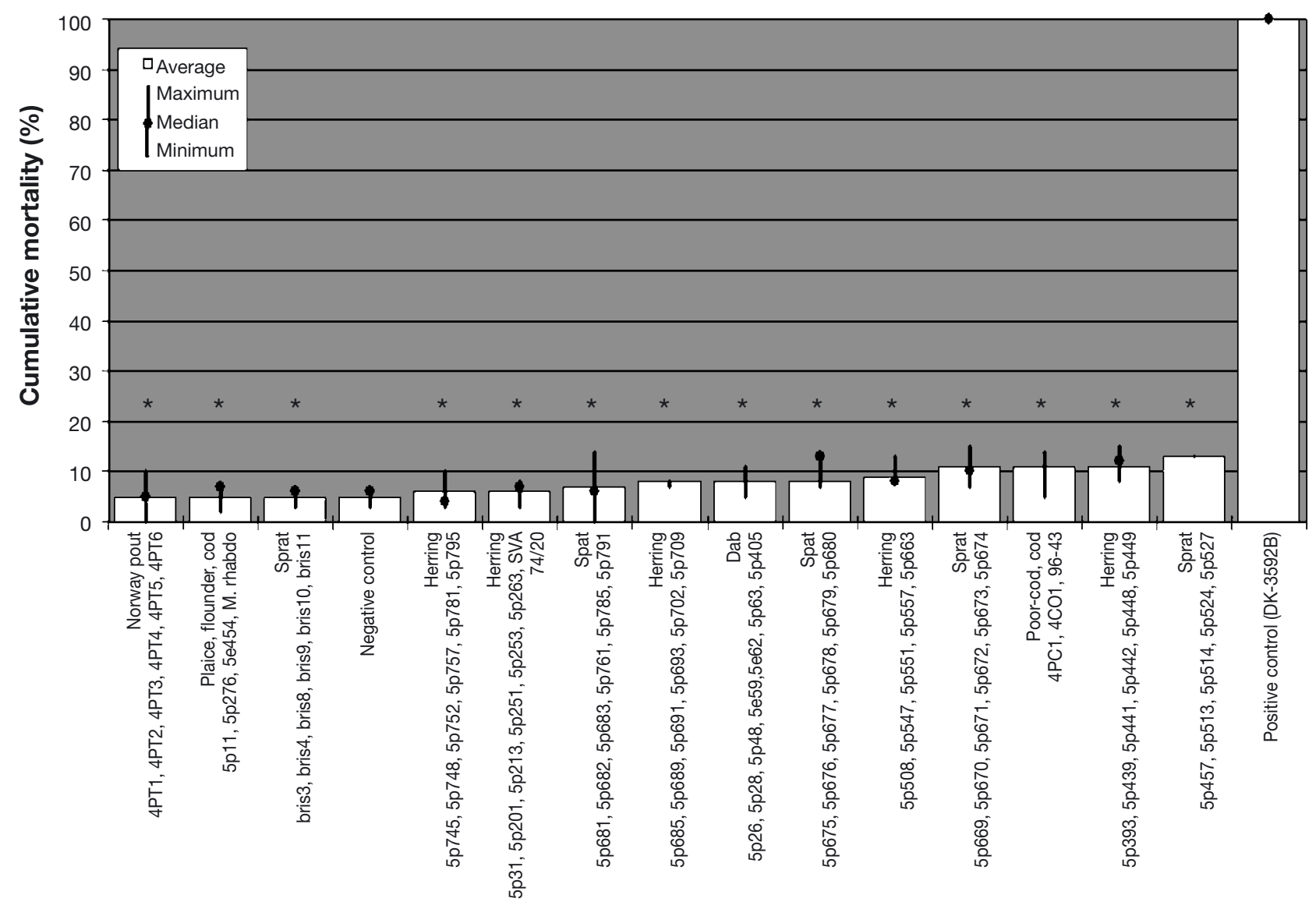

Fig. 3. Oncorhynchus mykiss. Cumulative mortality in Immersion Trial IV (size of fish = $0.6 \mathrm{~g}$ ) using VHSV isolates from wild marine fishes. Cumulative mortality at end of trial is shown as average, minimum, median and maximum mortality for each group. *Group not significantly different from negative control group. Isolate descriptions and specific names of host species are given in Table 1

rhages, exophthalmia, ascites, dark colouration), but to a lesser degree (especially the haemorrhages) than those exposed to the pathogenic DK-3592B. The mortality in all groups ranged from 13 to $42 \%$ and was significantly higher than the mortality in the negative control group injected with $0.9 \% \mathrm{NaCl}(4 \%)$.

The cumulative mortality within triplicates differed by 10 to 40 percent points when the positive and negative controls and the immersion trial were excluded. The groups infected with the herring isolate $1 \mathrm{p} 8$, the cod isolates and a group of miscellaneous isolates showed significant differences between the triplicate trials. Fish died after Day 13 within the group infected with the cod isolates in 2 of the triplicate tanks, but it was not possible to isolate VHSV from these fish. No fish died in the third tank after Day 13. VHSV was isolated from all 3 tanks from those fish that died before Day 13. Except for a few fish in each tank, VHSV was isolated from the fish that died in all 3 tanks in the group infected with the miscellaneous isolates. VHSV was isolated from all 3 tanks infected with $1 \mathrm{p} 8$.
Among the 161 fish that died from i.p. injection of marine VHSV isolates, the virus was recovered from 57 $(77 \%)$ of the 74 examined.

The results from this experiment showed that several of the VHSV isolates from marine fishes were pathogenic to rainbow trout when injected intraperitoneally, although the pathogenicity was lower than that of the positive control isolate DK-3592B. It could not be determined which pools of isolates were the most pathogenic due to the high variability among replicates within the groups.

Some of the fish died without clinical signs or bore ulcers from injuries inflicted by other fish. A variety of bacteria were cultured from these wounds, and proved to be normal flora of the water.

Again there was no reduction in pathogenicity by i.p. injection of a highly pathogenic virus pooled with a virus of lower pathogenicity, with the resulting mortality of $94 \%$ being very similar to the $97 \%$ in fish exposed to the pathogenic DK-3592B isolate and significantly higher than the group injected with $1 \mathrm{p} 8$ (average mortality 36\%; Fig. 2). 


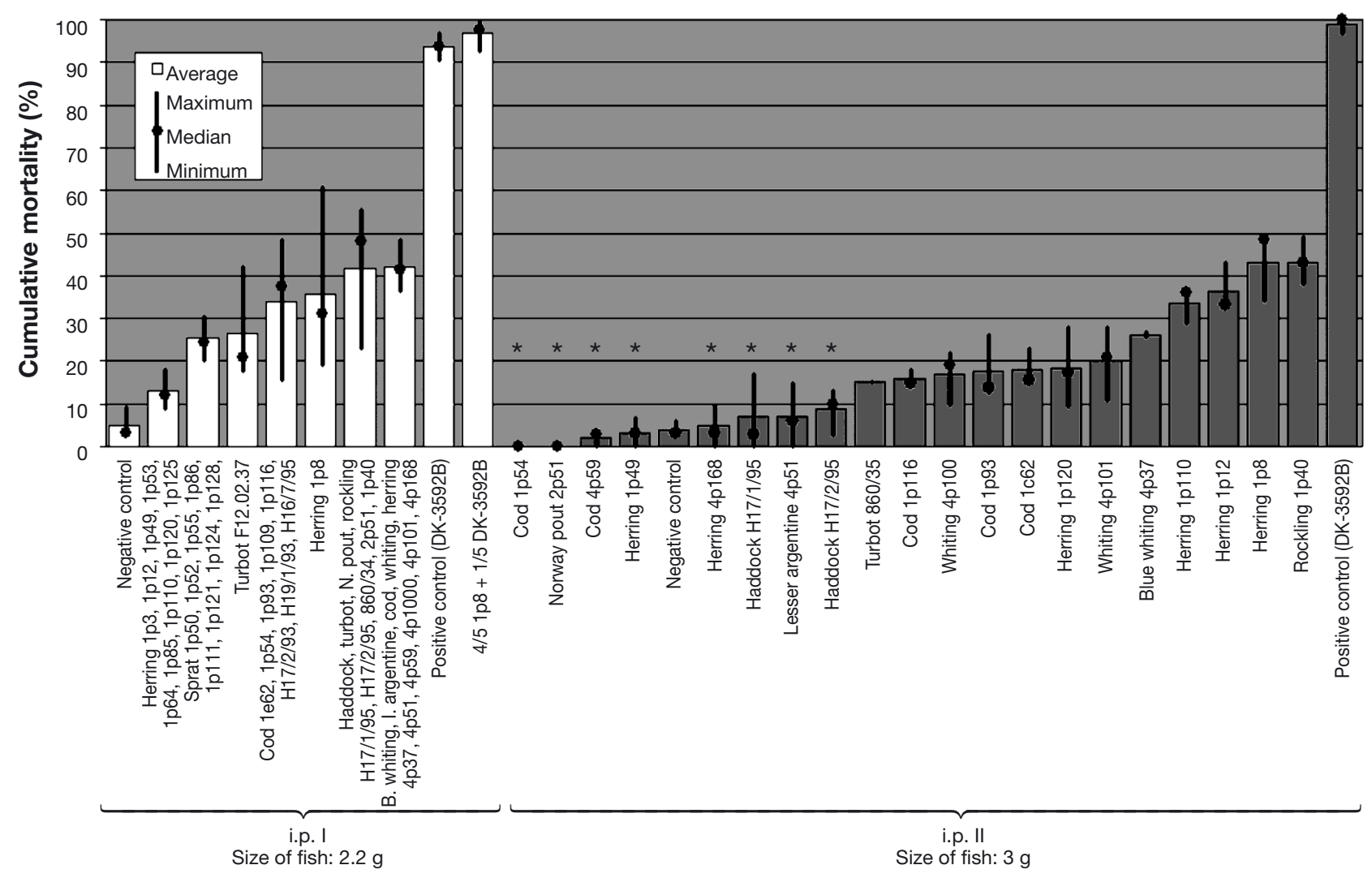

Fig. 4. Oncorhynchus mykiss. i.p. Trials I and II using VHSV isolates from wild marine fishes and from farmed turbot suspected to be of marine origin. Cumulative mortality at end of trial is shown as average, minimum, median and maximum mortality for each group. *Group not significantly different from negative control group. Isolate descriptions and specific names of host are given in Table 1

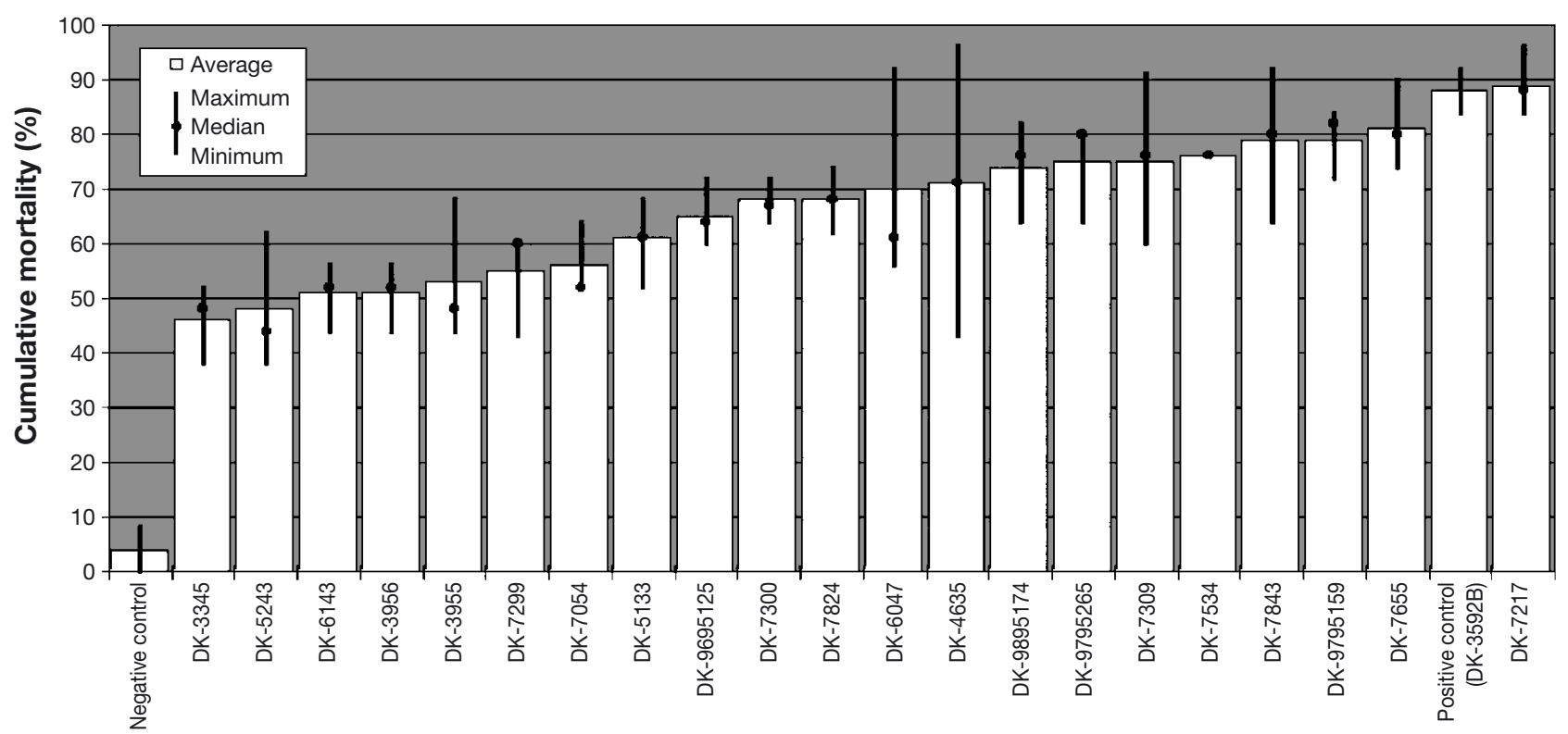

Fig. 5. Oncorhynchus mykiss. Immersion Trial V using VHSV isolates from farmed rainbow trout (size of fish = 6.2 g). Cumulative mortality at end of trial is shown as average, minimum, median and maximum mortality for each isolate. All groups were significantly different from negative control group. Isolate descriptions and specific names of host are given in Table 1 


\section{Injection Trial II and Immersion Trial III}

In the third trial (i.p. II), 20 of the 38 isolates injected as pools in Trial I were injected as individual isolates in $3 \mathrm{~g}$ rainbow trout (Fig. 4). In addition, the new isolates in i.p. Trial I were tested by immersion (Fig. 2). The mortality of injected fish ranged from 0 to $43 \%$, with 12 (60\%) of the marine VHSV isolates producing significantly higher mortality than the negative control. No mortality was observed in 2 groups. The cumulative mortality within replicates of the groups differed from 0 to $20 \%$ points, with no significant differences except for the positivecontrol immersion group and the group challenged intraperitoneally with the haddock isolate H17/1/95. In the latter group, 5 fish died in 1 tank, whereas only 0 and 1 fish, respectively, died in the other 2 tanks. VHSV was isolated from a pool of 2 fish from the tank with 5 dead fish, but not from the remaining dead fish in any of the tanks. The tank with the lowest mortality in the positivecontrol immersion group received less virus than the other 2 tanks due to an error; this may explain the lower cumulative mortality. VHSV was isolated from the fish that died from all 3 tanks.

The fish injected with most of the marine isolates showed typical signs of VHS, but these were again milder than those observed for fish exposed to the pathogenic DK-3592B. Those isolates producing mortality not statistically different from the negative control fish did not induce signs of disease.

Among the 336 fish that died from injection with the marine VHS viruses, 192 (57\%) were examined for virus in 142 pools (average: 1.4 fish pool $^{-1}$ ). VHSV was recovered from $110(78 \%)$ of the pools. We sampled 3 fish on Days 7 and 14 from the groups of fish challenged by immersion without isolation of VHSV, and from 8 groups challenged by i.p. injection from which no or only a few fish died. We missed sampling 1 tank from 1 group on Day 7, and another tank from 1 group on Day 14. Among the i.p.-injected fish, VHSV was re-isolated from 8 of 23 pools on Day 7, and from 5 of 23 pools on Day 14. All the isolates, except 1p54, were able to infect fish by the intraperitoneal route, although some did not result in mortality.

Intraperitoneal (i.p.) injection Trial II showed that some of the marine VHSV isolates were pathogenic when injected as single isolates, although their virulence was lower than that of the positive-control isolate DK-3592B. Pathogenicity was not correlated with the fish species from which the virus was originally isolated.

\section{Immersion Trial IV}

In the fourth trial, 77 new VHSV isolates from wild marine fishes and 2 older isolates were tested by immersion in $0.6 \mathrm{~g}$ rainbow trout fry. Except for the fry exposed to the positive control DK-3592B, very few exhibited signs of VHS. We exposed 14 triplicate groups of fish to pools of 3 to 7 virus isolates pooled according to the fish species of origin. The mortality ranged from 5 to $13 \%$ and did not differ significantly from the mortality in the negative control group immersed in culture medium without virus (5\%). Mortality in the positive control group was $100 \%$ (Fig. 3).

The cumulative mortality in the triplicate tanks differed from 0 to 14 percent points, and a statistical difference was observed in the groups exposed to sprat isolates 5p681, 5p682, 5p683, 5p761, 5p785 and 5p791, and the Norway pout isolates. VHSV was not isolated from any of the fish exposed to the Norway pout isolates. VHSV was isolated from 1 pool of dead fish from each of the 2 tanks exposed to the sprat isolates with the highest mortality but not from the tank with no mortality. At least 1 sample from each VHSV infected group was VHSV-positive, except for the group exposed to Norway pout isolates from the Scottish waters.

VHSV was isolated from fish sampled on Day 7 in 4 of the groups, fish sampled on Day 14 in 3 of the groups and from survivors in 3 of the groups.

This experiment confirmed the results of Immersion Trial I in that some marine isolates of VHSV can infect rainbow trout fry by the immersion route but do not induce mortality.

\section{Immersion Trial V-farmed rainbow trout isolates}

In the fifth trial, 22 VHSV isolates from farmed rainbow trout were tested by immersion in $6.2 \mathrm{~g}$ rainbow trout. All isolates were pathogenic for rainbow trout (Fig. 5). The groups were exposed to VHSV titres ranging from $1.4 \times 10^{4}$ to $4.4 \times$ $10^{5} \mathrm{TCID}_{50} \mathrm{ml}^{-1}$ water and cumulative mortality ranged from 46 to $89 \%$, with all exposed groups showing typical signs of VHS.

The cumulative mortality within replicates differed from 0 to 53 percent points with a statistical difference observed for isolates DK-6047 and DK-6435. VHSV was re-isolated from dead fish from all triplicate tanks in these groups.

All 3 neutralisation patterns were represented among the isolates with no significant correlation between neutralisation pattern and cumulative mortality (Fig. 6).

The year of isolation corresponded with cumulative mortality showed a slight tendency for older isolates to be less pathogenic than newer isolates, though this relationship was not very strong due to the broad distribution of data around the regression line (Fig. 7). 


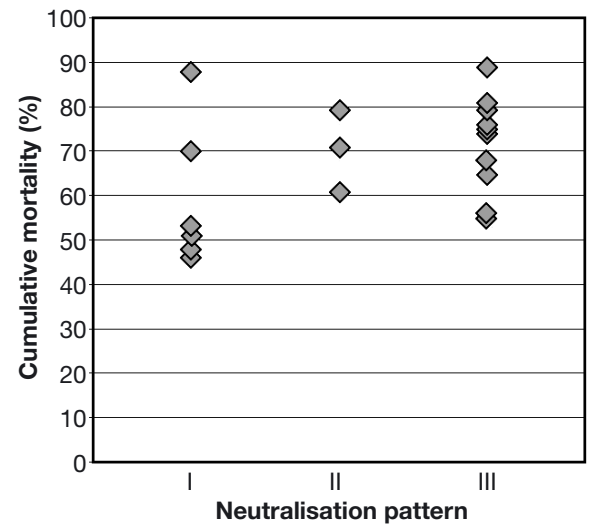

Fig. 6. Oncorhynchus mykiss. Immersion Trial V. Correlation between neutralisation pattern and cumulative mortality

Over the years there has been a shift in Denmark from Neutralisation Pattern I to II and then to III (Olesen et al. 1993), which is represented by the chosen isolates (Fig. 8).

Cumulative mortality did not appear to be influenced by the titre at challenge used in this trial $\left(>10^{4} \mathrm{TCID}_{50}\right.$ $\mathrm{ml}^{-1}$ water; Fig. 9).

No effect of immersion time on infection or mortality was observed.

\section{Statistical differences}

Even though there were statistical differences in cumulative mortality in 11 of the 95 sets of triplicate tanks, these differences were not accompanied by major differences in VHSV isolation from the affected tanks. They also did not alter the final conclusions in any of the individual trials.

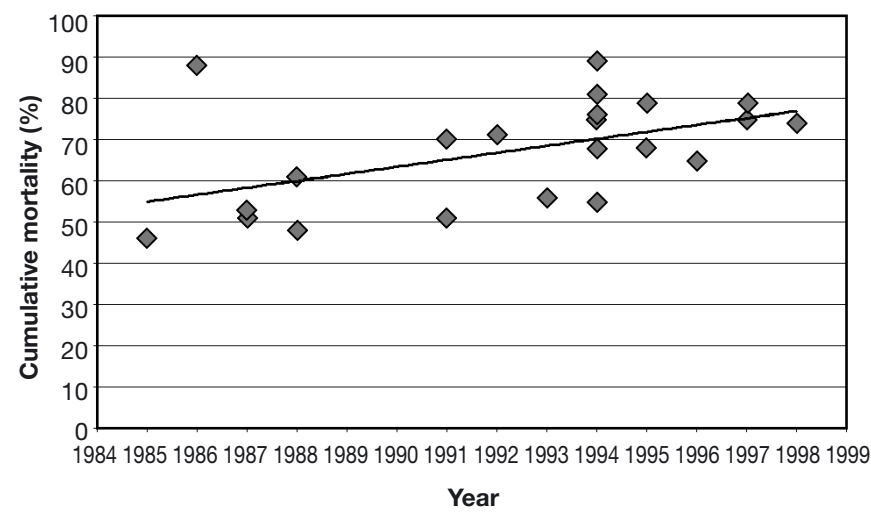

Fig. 7. Oncorhynchus mykiss. Immersion Trial V. Correlation between cumulative mortality and year of VHSV isolation

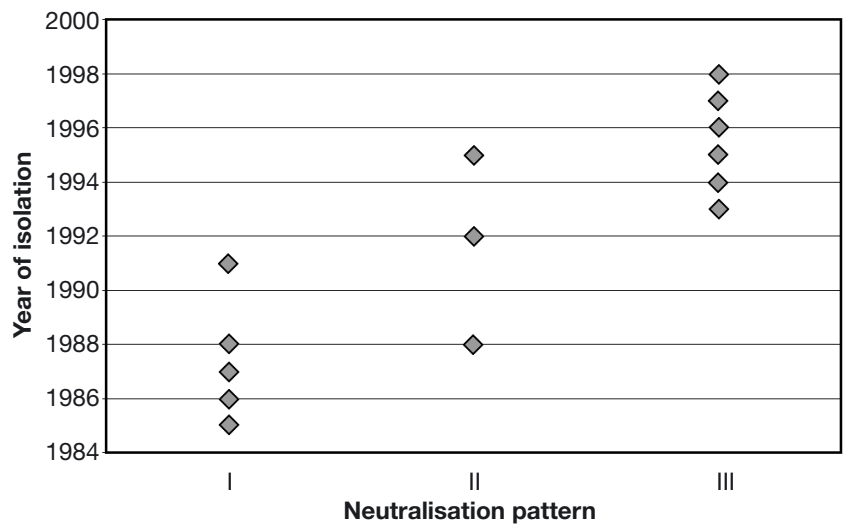

Fig. 8. Oncorhynchus mykiss. Immersion Trial V. Correlation between neutralisation pattern and year of VHSV isolation

\section{DISCUSSION}

The overall conclusion of these experiments is that VHSV isolates from wild marine fishes were generally non-pathogenic or of very low virulence by immersion challenge for rainbow trout of the size-group tested. Significant mortality with clinical signs of VHS was observed when wild marine fish isolates were injected intraperitoneally. Dixon et al. (1997) and our own previous observation showed no mortality in rainbow trout by immersion challenge with the Atlantic herring VHSV-isolate (96-43) and the Danish M. Rhabdo (Jensen et al. 1979) isolate. Conversely, Follett et al. 1997) demonstrated a low level of mortality (12\%) with clinical signs of VHS in rainbow trout fry exposed by immersion to a North American VHSV isolate from Pacific cod Gadus macrocephalus.

In Immersion Trial I and in i.p. Injection Trial II, the potential masking of a pathogenic virus by a non-

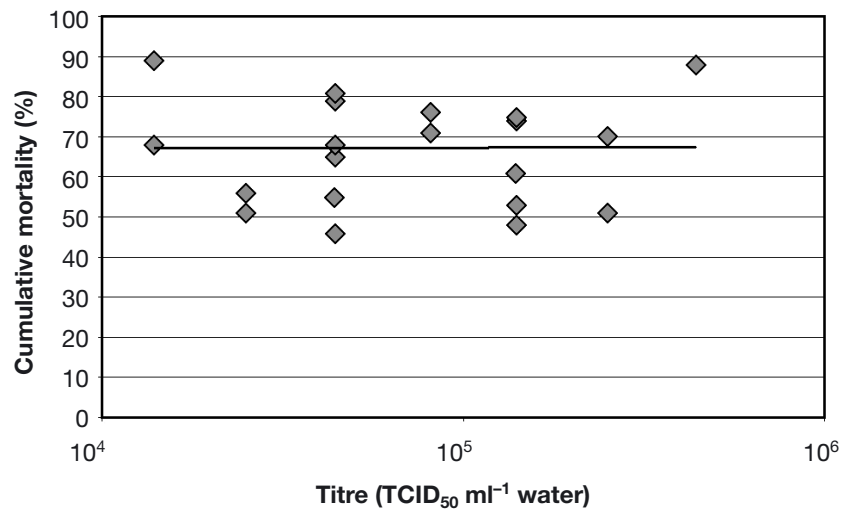

Fig. 9. Oncorhynchus mykiss. Immersion Trial V. Correlation between titre and cumulative mortality 
pathogenic virus was tested. Because the mortality curves for DK-3592B and 1p8 + DK-3592B were nearly identical in both trials, there did not appear to be any interference between the 2 isolates when pooled together for fish exposure. Therefore, for assessing the pathogenicity of large numbers of putative low-pathogenic VHSV isolates, the pooling of isolates can be recommended if, when mortality occurs, this is followed by an infection trial with each virus isolate.

Competition between pathogenic strains having different degrees of virulence was not directly investigated. Virological examination of rainbow trout infected by immersion and sampled on Days 7, 14 and at the end of the trials showed that the virus could be isolated from some fish, indicating infection that did not result in mortality (Table 2 ).

In contrast to the isolates from wild marine fishes, all the isolates from farmed rainbow trout were pathogenic by immersion challenge, regardless of whether they were from rainbow trout farmed in fresh water or sea water. Therefore, pathogenicity trials by immersion is a reliable way to differentiate between these 2 groups of VHSV isolates, and is at present the only available method.

Interestingly, the 2 farmed turbot isolates from Ireland and Scotland did not induce mortality in rainbow trout, supporting the view that these 2 isolates originated from the marine environment (Munro 1996, Snow et al. 1999).

The occurrence of VHS outbreaks among maricultured rainbow trout in Sweden in 1998 and 2000 (Nordblom 1998, Nordblom \& Norell 2000), and in Finland in 2000 (Husu-Kallio \& Suokko 2000) and later have caused concern. Continental Sweden and Finland are free of VHS, and it has not been possible to explain the source of origin by importation of fish. Sequencing of the Swedish isolate has suggested a marine origin, and the Finnish isolates from 2000 group together with isolates from wild fishes from the Baltic Sea, and early Danish isolates from farmed rainbow trout (K. Einer-Jensen, unpubl. data). Infection trials in rainbow trout using the Swedish and Finnish isolates from maricultured rainbow trout produced approximately $20 \%$ mortality for the Swedish isolates and $40 \%$ for the Finnish isolates (authors' unpubl. data). These isolates may therefore represent an intermediate stage of a marine isolate evolving towards pathogenicity. There is speculation that the early Danish VHSV isolates were marine wild fish isolates that became pathogenic in rainbow trout and originated the subsequent generations of pathogenic freshwater isolates. It is possible that a similar event is happening in Swedish and Finnish marine rainbow trout farms today.
Before the viral aetiology of VHS was established in the 1960s, there was speculation that the disease was caused by feeding farmed fish with raw marine fishes and thereby causing a Vitamin B deficiency (reviewed by Rasmussen 1965). Although a viral aetiology originating from marine fishes was not suspected at the time, the link may very well have been correct. Meyers \& Winton (1995) further suggested that freshwater VHSV may have evolved from marine reservoirs of VHSV that was introduced to the freshwater fish farms via feeding of raw marine fishes. Dixon (1999) reviewed the literature and concluded that there is evidence for the transfer of VHSV originating from the marine environment to fresh water.

Snow et al. (1999) have also shown that marine VHSV isolates are closely related to farmed rainbow trout isolates. Sequencing of VHSV isolates of both wild and farmed fish origin have neither revealed a marker of origin nor a marker of pathogenicity (K. Einer-Jensen, Danish Veterinary Institute, pers. comm.). However, alignment studies of full-length sequences of the viral G-gene show clustering of marine isolates in distinct groups (K. Einer-Jensen et al. unpubl. data). To our knowledge, it has not been possible to produce monoclonal antibodies specific to the marine VHSV isolates.

Despite the very close serologic and genetic relationship between VHSV isolates from wild marine fishes and farmed rainbow trout, none of the large number of VHSV isolates from wild marine fishes tested by immersion were pathogenic to rainbow trout in the present study. Overall, these results suggest that a few mutations in the viral genome of VHSV could be sufficient to transform a non- or low-pathogenic VHSV isolate into an isolate that is highly pathogenic for rainbow trout. Our studies showed that the marine isolates can be potentially pathogenic, causing mortality when the isolates are injected intraperitoneally. Snow \& Cunningham (2000) observed an increase in virulence of Isolate 860/94 following 5 passages in rainbow trout, although this increased virulence was not accompanied by a difference in the consensus sequence of the glycoprotein gene. Therefore, a non-pathogenic form of VHSV may revert to a pathogenic form after passage through rainbow trout. Alternatively, a wild marine fish isolate of VHSV may exist that is pathogenic for rainbow trout by immersion, despite the lack of evidence to this effect in our study. If either of these possibilities is true, then anadromous fishes could transport marine VHSV upstream to rainbow trout fish farms and initiate a VHS outbreak.

When fishes are infected with VHSV, the TCID $_{50} \mathrm{~g}^{-1}$ tissue can become high. Snow \& Cunningham (2000) reported $10^{6}$ to $10^{8} \mathrm{TCID}_{50} \mathrm{~g}^{-1}$ fish tissue, while Kocan et al. (1997) reported up to $10^{7.7}$ plaque-forming units (PFU) 
$\mathrm{g}^{-1}$ tissue in herring experimentally infected with the North American VHSV isolate. In our study, we found that the titres for the marine isolates in whole infected rainbow trout were between $2.2 \times 10^{2}$ and $7.1 \times 10^{7}$ $\mathrm{TCID}_{50} \mathrm{~g}^{-1}$ fish (i.p. Trial I). In Immersion Trial V (rainbow trout VHSV isolates), VHSV-positive fish titres for tissue material were between $1.3 \times 10^{6}$ and $1.3 \times 10^{9} \mathrm{TCID}_{50} \mathrm{~g}^{-1}$.

Among wild fishes, high VHSV titres have also been reported. VHSV titres of confined herring in the closedpound spawn-on-kelp fishery in Alaska were as much as $10^{8} \mathrm{PFU} \mathrm{g}^{-1}$ (Hershberger et al. 1999). Confined herring and sand lances captured in Puget Sound developed VHS, with titres up to $10^{8} \mathrm{PFU} \mathrm{g}^{-1}$ tissue and from $3 \times 10^{5}$ to $4 \times 10^{6} \mathrm{PFU} \mathrm{g}^{-1}$ tissue, respectively. One (not confined) herring tested VHS-positive with titres of $3.3 \times 10^{5} \mathrm{PFU}$ $\mathrm{g}^{-1}$ (Kocan et al. 2001), while Traxler et al. (1999) reported titres of $1.6 \times 10^{6} \mathrm{PFU} \mathrm{g}^{-1}$ tissue in wild herring and pilchard during a VHSV outbreak in Canada. These high titres increase the concern that the concentration of VHSV in marine fishes could be sufficient to transmit the virus if they are fed to farmed fishes. Therefore, feeding raw minced fish to farmed fish cannot be recommended. This view was further supported by Amos et al. (1998) when examining management strategies for VHSV in Washington State.

Collectively, all these studies validate the possibility of farmed rainbow trout contracting VHSV from wild marine fishes, raising further concern for the long-term management of VHSV in the marine environment. In order to determine the degree of risk this reservoir poses, and consequently how VHSV in the marine environment should be dealt with legislatively, it is important to identify the characteristics that confer virulence to VHSV isolates and how a non-pathogenic isolate can revert to a virulent form.

Acknowledgements. We thank Torben Egil Kjær, Vibeke Petersen, Mogens Gam Jensen and Lene Nørskov for technical assistance in the aquarium facilities. Mette Storgaard Lorenzen, Mette Eliassen, Nicole Nicolajsen, Sanne Madsen, Maria Ripa Damhoff and Jette Mølgaard are thanked for technical assistance with the virological analysis. Anders Hellström from the National Veterinary Institute (Statens Veterinärmedicinska Anstalt, SVA), Sweden, is thanked for providing the Isolate SVA 74-20. John McArdle from the Department of Marine Fisheries Research Centre, Ireland, is thanked for providing Isolate F13.02.97. This research was carried out under the EC project 'Rhabdoviruses in Wild Marine Fish in European Coastal Waters: Characterisation and Significance for Aquaculture', FAIR CT 96.1594. The research school SCOFDA (Sustainable Control of Fish Diseases in Aquaculture) is also thanked for financial support.

\section{LITERATURE CITED}

Amos K, Thomas J, Hopper K (1998) A case history of adaptive management strategies for viral hemorrhagic sep- ticemia virus (VHSV) in Washington State. J Aquat Anim Health 10:152-159

Brudeseth BE, Evensen $\varnothing$ (2002) Occurrence of viral haemorrhagic septicaemia virus (VHSV) in wild marine fish species in the coastal regions of Norway. Dis Aquat Org $52: 21-28$

Brunson R, True K, Yancey J (1989) VHS virus isolated at Makah National Fish Hatchery. Am Fish Soc Newsl (Fish Health Sect) 17:3-4

Cox B, Hedrick R (2001) VHS virus in Pacific sardines and mackerel. Am Fish Soc Newsl (Fish Health Sect) 29:6

Dixon PF (1999) VHSV came from the marine environment: clues from the literature, or just red herrings? Bull Eur Assoc Fish Pathol 19:60-65

Dixon PF, Feist S, Kehoe E, Parry L, Stone DM, Way K (1997) Isolation of viral haemorrhagic septicaemia virus from Atlantic herring Clupea harengus from the English Channel. Dis Aquat Org 30:81-89

Dunn OJ (1977) Basic statistics: a primer for the biomedical sciences second edition. John Wiley \& Sons, New York

Follett JE, Meyers TR, Burton TO, Geesin JL (1997) Comparative susceptibilities of salmonid species in Alaska to infectious hematopoietic necrosis virus (IHNV) and North American viral hemorrhagic septicemia virus (VHSV). J Aquat Anim Health 9:34-40

Hershberger PK, Kocan RM, Elder NE, Meyers TR, Winton JR (1999) Epizootiology of viral hemorrhagic septicemia virus in Pacific herring from the spawn-on-kelp fishery in Prince William Sound, Alaska, USA. Dis Aquat Org 37:23-31

Husu-Kallio J, Suokko M (2000) Two outbreaks of VHS (viral hemorrhagic septicaemia) in Finland. Report for the Standing Veterinary Committee. Ministry of Agriculture and Forestry, Veterinary and Food Department, Helsinki

Jensen NJ, Bloch B, Larsen JL (1979) The ulcus-syndrome in cod (Gadus morhua). III. A preliminary virological report. Nord Vetmed 31:436-442

Jørgensen PEV, Olesen NJ (1987) Cod ulcus syndrome rhabdovirus is indistinguishable from the Egtved (VHS) virus. Bull Eur Assoc Fish Pathol 7:73-74

King JA, Snow M, Skall HF, Raynard RS (2001a) Experimental susceptibility of Atlantic salmon Salmo salar and turbot Scophthalmus maximus to European fresh water and marine isolates of viral haemorrhagic septicaemia virus. Dis Aquat Org 47:25-31

King JA, Snow M, Smail DA, Raynard RS (2001b) Distribution of viral haemorrhagic septicaemia virus in wild fish species of the North Sea, north east Atlantic Ocean and Irish Sea. Dis Aquat Org 47:81-86

Kocan R, Bradley M, Elder N, Meyers TR, Batts WN, Winton JR (1997) North American strain of viral hemorrhagic septicemia virus is highly pathogenic for laboratory-reared Pacific herring. J Aquat Anim Health 9:279-290

Kocan RM, Hershberger PK, Elder NE, Winton JR (2001) Epidemiology of viral hemorrhagic septicemia among juvenile Pacific herring and Pacific sand lances in Puget Sound, Washington. J Aquat Anim Health 13:77-85

Lorenzen N, Olesen NJ, Jørgensen PEV (1988) Production and characterization of monoclonal antibodies to four Egtved virus structural proteins. Dis Aquat Org 4:35-42

Lorenzen N, Olesen NJ, Jørgensen PEV (1993) Antibody response to VHS virus proteins in rainbow trout. Fish Shellfish Immunol 3:461-473

Meyers TR, Winton JR (1995) Viral hemorrhagic septicemia virus in North America. Annu Rev Fish Dis 5:3-24

Meyers TR, Short S, Lipson K (1999) Isolation of the North American strain of viral hemorrhagic septicemia virus (VHSV) associated with epizootic mortality in two new host 
species of Alaskan marine fish. Dis Aquat Org 38:81-86

Mortensen HF, Heuer OE, Lorenzen N, Otte L, Olesen NJ (1999) Isolation of viral haemorrhagic septicaemia virus (VHSV) from wild marine fish species in the Baltic Sea, Kattegat, Skagerrak and the North Sea. Virus Res 63: 95-106

Munro ALS (1996) Report of the first recorded outbreak of viral haemorrhagic septicaemia (VHS) in GB and subsequent actions to contain, eradicate and investigate the origins of the infection. Scottish Aquaculture Research Report 3. The Scottish Office Agriculture, Environment and Fisheries Department, Aberdeen

Nordblom B (1998) Report on an outbreak of viral haemorrhagic septicaemia in Sweden. Swedish Board of Agriculture, Jönköping

Nordblom B, Norell AW (2000) Report on an outbreak of VHS (viral hemorrhagic septicaemia) in farmed fish in Sweden. Report for the Standing Veterinary Committee. Swedish Board of Agriculture, Department for Animal Production and Health, Jönköping

Olesen NJ, Jørgensen PEV (1991) Rapid detection of viral haemorrhagic septicaemia virus in fish by ELISA. J Appl Ichthyol 7:185-186

Olesen NJ, Lorenzen N, Jørgensen PEV (1993) Serological differences among isolates of viral haemorrhagic septicaemia virus detected by neutralizing monoclonal and polyclonal antibodies. Dis Aquat Org 16:163-170

Rasmussen CJ (1965) A biological study of the Egtved disease (INUL). Ann NY Acad Sci 126:427-460

Editorial responsibility: Jo-Ann Leong, Kaneohe, Hawaii, USA
Ross K, McCarthy U, Huntly PJ, Wood BP, Stuart D, Rough EI, Smail DA, Bruno DW (1994) An outbreak of viral haemorrhagic septicaemia (VHS) in turbot (Scophthalmus maximus) in Scotland. Bull Eur Assoc Fish Pathol 14:213-214

Smail DA (1995) Isolation and identification of viral haemorrhagic septicaemia (VHS) virus from North Sea cod (Gadus morhua L.). Int Counc Explor Sea Comm Meet 1995/F:15

Smail DA (2000) Isolation and identification of viral haemorrhagic septicaemia (VHS) viruses from cod Gadus morhua with the ulcus syndrome and from haddock Melanogrammus aeglefinus having skin haemorrhages in the North Sea. Dis Aquat Org 41:231-235

Snow M, Cunningham CO (2000) Virulence and nucleotide sequence analysis of marine viral haemorrhagic septicaemia virus following in vivo passage in rainbow trout Oncorhynchus mykiss. Dis Aquat Org 42:17-26

Snow M, Cunningham CO, Melvin WT, Kurath G (1999) Analysis of the nucleoprotein gene identifies distinct lineages of viral haemorrhagic septicaemia virus within the European marine environment. Vir Res 63:35-44

Takano R, Nishizawa T, Arimoto M, Muroga K (2000) Isolation of viral haemorrhagic septicaemia virus (VHSV) from wild Japanese flounder, Paralichthys olivaceus. Bull Eur Assoc Fish Pathol 20:186-192

Traxler GS, Kieser D, Richard J (1999) Mass mortality of pilchard and herring associated with viral hemorrhagic septicemia virus in British Columbia, Canada. Am Fish Soc Newsl (Fish Health Sect) 27:3-4

Submitted: October 5, 2001; Accepted: June 13, 2003 Proofs received from author(s): February 9, 2004 